\title{
Sinopse do gênero Strongylaspis Thomson, 1860 (Coleoptera, Cerambycidae, Prioninae, Macrotomini)
}

Marcela L. Monné ${ }^{1,3}$

Antonio Santos-Silva ${ }^{2}$

\begin{abstract}
Synopsis of the genus Strongylaspis Thomson, 1860 (Coleoptera, Cerambycidae, Prioninae, Macrotomini). The genus Strongylaspis Thomson, 1860 with its twelve known species are briefly treated herein: S. batesi Lameere, 1903, S. bullatus Bates, 1872, S. championi Bates, 1884, S. corticarius (Erichson, 1848), S. dohrni Lameere, 1903, S. fryi Lameere, 1912, S. graniger Bates, 1884, S. hirticollis Tippmann, 1953, S. kraepelini Lameere, 1903, S. macrotomoides Tippmann, 1953, S. sericans Tippmann, 1953, S. sericeus Zajciw, 1970. The genus as well as the species, Strongylaspis championi, $S$. bullatus and $S$. corticarius are redescribed; the last one including characterization of wings and male and female terminalia. Four new species are added: S. aureus sp. nov. (BRASIL, Amazonas), S. migueli sp. nov. (BRASIL, Mato Grosso), S. christianae sp. nov. (BRASIL, Mato Grosso) and S. bolivianus sp. nov. (BOLIVIA). All the species, but $S$. dohrni, are illustrated and keyed. Maps of distribution are also given.
\end{abstract}

Keywords. Cerambycidae; Coleoptera; Macrotomini; Strongylaspis; taxonomy.

\section{INTRODUÇÃO}

O gênero Strongylaspis Thomson, 1860 está representado por doze espécies americanas (MonNé, 1995) e seu estudo permitiu o reconhecimento de quatro espécies novas, três para o Brasil e uma para a Bolívia, totalizando dezesseis espécies para o gênero. $O$ gênero é redescrito, assim como as seguintes espécies: Strongylaspis championi Bates, 1884, S. bullatus Bates, 1872 e $S$. corticarius (Erichson, 1848), desta última são descritas, também, asas e terminálias do macho e da fêmea. São fornecidos chave para identificação e mapas de ocorrência (Figs. 28, 29) com dados das descrições originais e do material examinado.

ThOMson (1860) descreveu Strongylaspis para S. scobinatus proveniente do México e o arrolou no grupo "Prionitae Verae", na divisão "Macrotomitae" por apresentar a cabeça posteriormente não prolongada em colo e antenômero III mais longo que os seguintes.

LACORDAIRE (1869) arrolou o gênero na legião "Prionides Vrais", formada por prionídeos com tarsos munidos de escova no lado inferior e tarsômero III bilobado; coorte "Prionides vrais Sylvains", caracterizada pela saliência intercoxal do abdome em triângulo agudo; seção "A", metepisternos mais ou menos largos, paralelos ou subparalelos; grupo
"Macrotomides", com lígula pequena e inteira, protórax denticulado lateralmente, escapo muito mais curto do que o antenômero III.

Bates (1884) transferiu Ergates corticarius para Strongylaspis. LAMEere (1903) propôs a sinonímia entre Strongylaspis scobinatus, espécie tipo, e S. corticarius, revisou o gênero alocando-o no grupo "Macrotomines", subdivisão "Cnémoplitiens" e dividiu-o em três subgêneros: $S$. (Chiasmetes) Pascoe, 1867, S (Curitiba) e S. (Strongylaspis).

Fragoso \& Monné (1995) elevaram os subgêneros Chiasmetes e Curitiba a gênero.

Apenas se conhece a planta-hospedeira de Strongylaspis kraepelini parvula Linsley e Chemsak, 1966: Scalesia pedunculata Hooker (Asteraceae). LinsLey \& CHEMSAK (1966) comentaram que larvas e pupas foram coletadas em tronco podre.

O gênero é exclusivamente americano (Figs. 28, 29) e a maioria das espécies ocorre na América do Sul (11), seguida da América Central (4) e da América do Norte (3). Somente duas espécies ocorrem em mais de um subcontinente: $S$. corticarius (presente nas três Américas) e S. bullatus (Américas Central e do Norte).

Considerando a publicação de catálogo recente (MonNé, 1995), as citações bibliográficas mencionadas sob cada táxon

1. Departamento de Zoologia, Universidade Federal do Paraná. Caixa Postal 19020, 81531-990 Curitiba-PR, Brasil.

2. Museu de Zoologia, Universidade de São Paulo. Caixa Postal 42594, 04299-970 São Paulo-SP, Brasil.

3. Bolsista CAPES. 
restringem-se à descrição original e à citação do catálogo, mas, quando pertinente, outras citações são acrescidas.

A terminologia empregada segue NAPP (1994) e MARQUES \& NAPP (1996), complementada por MARINONI \& AlMEIDA (1983) para venação alar.

As abreviaturas citadas no texto correspondem às seguintes instituições: BMNH, The Natural History Museum, Londres; CASC, California Academy of Sciences, São Francisco; DZUP, Departamento de Zoologia, Universidade Federal do Paraná, Curitiba; ISNB, Institut Royal des Sciences Naturelles de Belgique, Bruxelas; MCNZ, Museu de Ciências Naturais, Fundação Zoobotânica do Rio Grande do Sul, Porto Alegre; MCSN, Museo Civico di Storia Naturali "Giacomo Doria", Gênova; MNHN, Muséum National d'Histoire Naturelle, Paris; MNRJ, Museu Nacional, Universidade Federal do Rio de Janeiro, Rio de Janeiro; MZSP, Museu de Zoologia, Universidade de São Paulo, São Paulo; NHRS, Naturhistoriska Riksmuseet, Estocolmo; USNM, National Museum of Natural History, Washington; ZMHB, Museum für Naturkunde der Humboldt-Universität, Berlim; ZMPA, Museum of the Institute de Zoology, Polish Academy of Science, Varsóvia; ZMUH, Zoologisches Institut und Zoologisches Museum, Universität von Hamburg, Hamburgo.

\section{Strongylaspis Thomson, 1860}

Strongylaspis Thomson, 1860: 313; Monné \& Giesbert, 1993: 7; Monné, 1995: 2; Chemsak, 1996: 70; Martínez, 2000: 79.

Espécie-tipo. Strongylaspis scobinatus Thomson, 1860, monotipia (= Ergates corticarius Erichson, 1848).

Tamanho: 17 a $38 \mathrm{~mm}$. Colorido geral do tegumento marrom (diversos matizes). Pilosidade amarelada ou dourada.

Cabeça subvertical, com depressão longitudinal entre os tubérculos anteníferos; escultura formada por pontos e grânulos; tubérculos anteníferos salientes; labro transversal e com pilosidade densa e longa; lígula pouco desenvolvida, coriácea e sem lobos na maioria das espécies (maior e semibilobada em $S$. sericeus). Olhos variáveis em tamanho, pouco sinuosos na borda anterior; lobos superiores aproximados a afastados; lobos inferiores tão ou mais afastados que os superiores. Mandíbulas curtas e subtriangulares; superfície dorsal convexa, densamente pontuada e pilosa.

Antenas filiformes, nos machos, no máximo, alcançando os ápices elitrais; nas fêmeas, no máximo, alcançando o terço apical; escapo robusto, pontuado ou áspero, mais longo do que o antenômero III, na maioria das espécies; antenômero III mais longo do que o IV; antenômeros IX - XI estriados; antenômeros III - XI carenados na face ventral.

Protórax transversal, crenulado nas margens laterais; ângulos anteriores salientes ou não; ângulos posteriores munidos de espinhos, em geral longos. Tegumento do pronoto com desenho brilhante distinto ou não; machos, na maioria das espécies, com pontuação sexual evidente. Processo mesosternal com lados paralelos e ápice bilobado. Escutelo convexo, arredondado posteriormente, sulco longitudinal indistinto ou ausente e superfície com asperezas.
Élitros alongados, subparalelos; superfície, no terço basal, com asperezas ou grânulos mais cerrados do que nos $2 / 3$ apicais.

Urosternito I o mais longo; urosternitos II-IV subiguais em comprimento; último urosternito com ápice arredondado ou fortemente chanfrado.

Pernas com pilosidade variável; pernas anteriores dos machos, em geral mais longas do que as demais; profêmures e protíbias dos machos ásperos ou pontuados; tíbias com escova de pêlos no lado ventral (principalmente as protíbias); protarsos alargados nos machos; tarsômero I alongado em todas as pernas.

Discussão. Strongylaspis é muito semelhante a Chiasmetes Pascoe, 1867 e Curitiba Lameere, 1903, com os quais compartilha a forma convexa do escutelo. Difere de ambos por não apresentar o escutelo dividido longitudinalmente por sulco liso. Examinamos exemplares de $S$. batesi Lameere, 1903 que apresentam o escutelo dividido por sulco, mas nunca liso, profundo e estendendo-se até o ápice como em Chiasmetes. Strongylaspis difere ainda de Chiasmetes por apresentar sulco bem marcado na região dorsal da cabeça.

Strongylaspis também é semelhante a Protorma Waterhouse, 1880, principalmente pela forma e escultura da cabeça (inclusive mandíbulas), protórax e antenas. Difere notavelmente pela forma do escutelo que, em Protorma, é suavemente côncavo, com as bordas laterais elevadas.

Chave para as espécies de Strongylaspis

1. Episternos protorácicos reduzidos na fêmea (macho desconhecido). MÉXICO

S. dohrni Lameere, 1903

Episternos protorácicos normais 2

2(1). Élitros com pilosidade conspícua (Figs. 1-5), destacandose da coloração do tegumento (em geral formando tufos).

Élitros glabros ou com pilosidade uniforme, não destacada da coloração geral do tegumento (Figs. 6-17)

3(2). Cabeça e pronoto somente com pilosidade decumbente

Cabeça e pronoto com pêlos longos, eretos e abundantes além da pilosidade decumbente$$
5
$$

4(3). Pilosidade dourada na região dorsal; antenas dos machos atingindo o quarto apical dos élitros (fêmea desconhecida) (Fig. 1). BRASIL (Amazonas) ......... S. aureus sp. nov.

Pilosidade amarelada na região dorsal; antenas dos machos atingindo o meio dos élitros (Fig. 2). BRASIL ( Bahia, Espírito Santo) S. sericeus Zajciw, 1970 
5(4). Pronoto com desenho do tegumento brilhante em forma de "Y" e nitidamente destacado (Fig. 3). BRASIL (Mato Grosso) . S. fryi Lameere, 1912

Pronoto com desenho do tegumento pouco ou nãodestacado, constituído por tubérculos e saliências

... 6

6(5). Região circum-escutelar com grânulos numerosos e concentrados; lobos oculares superiores tão distantes entre si quanto os inferiores (macho desconhecido) (Fig. 5). COLÔMBIA

S. hirticollis Tippmann, 1953

Região circum-escutelar com grânulos esparsos; lobos oculares superiores mais distantes entre si do que os inferiores (Fig. 4). COLÔMBIA

S. sericans Tippmann, 1953

7(2). Élitros com grânulos em toda extensão (Fig. 17). PANAMÁ S. graniger Bates, 1884

Élitros com grânulos, no máximo, até a metade basal ...8

8(7). Pronoto com pêlos longos e evidentes ......................... 9

Pronoto glabro ou pubescente, sem pêlos longos .....10

9(8). Cabeça fortemente deprimida entre os lobos oculares superiores; protórax com ângulos anteriores nãoprojetados; ângulos suturais dos élitros inermes (macho desconhecido) (Fig. 7). BOLÍVIA

S. bolivianus sp. nov.

Cabeça ligeiramente deprimida entre os lobos oculares superiores; protórax com ângulos anteriores projetados; ângulos suturais dos élitros com espinho (Fig. 6). MÉXICO, GUATEMALA, COSTARICA S. championi Bates, 1884

10(8). Élitros de cor avelã, nitidamente contrastante com a coloração do restante do corpo (Figs. 8, 9). BRASIL (Rondônia, Mato Grosso)

S. migueli sp. nov.

Élitros com outra coloração e não-contrastante com a coloração do restante do corpo 11

11(10). Superfície do pronoto com duas saliências longitudinais curtas, brilhantes; pronoto e élitros com pubescência densa (Fig. 10). MÉXICO, NICARÁGUA S. bullatus Bates, 1872

Superfície do pronoto de outra forma; pronoto e élitros glabros ou com pubescência esparsa .. 12

12(11). Vértice sem grânulos e com pontuação grossa e confluente

Vértice com grânulos pequenos, esparsos e pontuação fina 15

13(12). Abdome quase glabro (Fig. 11). PERU, BRASIL (Rondônia, Amazonas, Mato Grosso, Santa
Catarina) S. christianae sp. nov.

Abdome com pilosidade abundante ... 14

14(13). Élitros grosseiramente ásperos em torno do escutelo, este convexo (Fig. 12). EQUADOR S. kraepelini kraepelini Lameere, 1903

Élitros finamente ásperos em torno do escutelo, este pouco convexo (Fig. 13). EQUADOR (Ilhas Galápagos)

... S. kraepelini parvula Linsley \& Chemsak, 1966

15(12). Escutelo e região circum-escutelar com grânulos finos e numerosos (Fig. 14). ESTADOS UNIDOS DA AMÉRICA(Florida) ao PANAMÁ, VENEZUELA, BRASIL (Roraima), GUIANA, CUBA, JAMAICA, DOMINICA ........... S. corticarius (Erichson, 1848)

Escutelo e região circum-escutelar com grânulos grossos e menos numerosos 16

16(15). Pronoto com desenho do tegumento brilhante nítido em forma de "X" (Fig. 16). COLÔMBIA S. macrotomoides Tippmann, 1953 Pronoto sem desenho distinto (Fig. 15). BRASIL (Bahia a São Paulo), PARAGUAI, ARGENTINA ........... S. batesi Lameere, 1903

\section{Strongylaspis dohrni Lameere, 1903}

Strongylaspis (Strongylaspis) Dohrni Lameere 1903: 30; Tippmann, 1953: 187 (nota); Zajciw, 1970: 1 (nota); Chemsak et al., 1992: 16 (cat.); Monné 1995: 3 (cat.); Noguera \& Chemsak, 1996: 396.

Não obtivemos nenhum exemplar que se enquadrasse na descrição de LAMEERE (1903). TippMANN (1953) afirmou que o holótipo fêmea, da coleção Dohrn, foi destruído juntamente com o "Museum of Stettin", Polônia, durante a 2a Guerra Mundial. No entanto, Tomasz Huflest (comunicação pessoal), curador do ZMPA, escreveu-nos: "Hereby I inform you that the type of Strongylaspis dohrni survived the war and now it belongs to our collection. This specimen has the following labels: Type [red label] ; Mexico Stark. [green label] ; 364 ; Strongylaspis Dohrni Lameere Type [with female symbol] ; Museum Zoologicum Polonicum Warszawa 12/45."

A inclusão da espécie na chave foi baseada apenas na descrição original. S. dohrni assemelha-se a S. championi, distinguindo-se principalmente: pronoto com granulações grossas; proepisternos muito reduzidos; pontuação do abdome mais cerrada e áspera.

\section{Strongylaspis aureus sp. nov.}

(Figs. 1,29)

Etimologia . Latim, aureus $=$ dourado, alusivo ao colorido dos pêlos da região dorsal.

Macho. Colorido geral do tegumento marrom-escuro e opaco. Pilosidade dourada na região dorsal (Fig. 1), trocanteres 
e escovas tarsais, e amarelada na região ventral. Cabeça com duas faixas de pêlos dourados estendidas desde a região posterior dos olhos até à base dos tubérculos anteníferos, em forma de tufo nas extremidades e ralas e estreitas no meio. Distância entre os lobos oculares superiores um terço maior do que a largura de um lobo; lobos inferiores muito mais afastados do que os superiores. Carena ocular pouco aparente e restrita ao ápice do lobo ocular superior. Sutura epistomal indistinta. Sutura coronal bem marcada, profunda e larga entre os olhos. Clípeo rugoso, com pêlos curtos e esparsos. Labro finamente rugoso, com pilosidade curta e esparsa na base, e adensada para o ápice. Genas com pontos finos e pêlos curtos; ápices obtusos e pouco projetados. Submento deprimido; superfície com pontos cerrados e confluentes, grânulos e pêlos esparsos; borda anterior elevada, sub-lisa e com alguns pêlos eretos. Gula indistintamente separada do submento, com pontos cerrados e confluentes, grânulos e pêlos esparsos. Mandíbulas, no dorso e na face lateral externa, com pontos grossos e profundos e pêlos esparsos, longos e curtos; ápices lisos e glabros. Antenas alcançando o quarto apical dos élitros; escapo grosseiramente pontuado; antenômero III um quinto mais curto que os IV-V reunidos; III-VI pontuados no dorso e pontuado-estriados ventralmente, adensados para o ápice; VIII-IX pontuados no dorso e apenas estriados ventralmente; $\mathrm{X}$-XI inteiramente estriados; XI cerca de 1,5 vezes o comprimento do $X$.

Pronoto (Fig. 1) com desenho do tegumento brilhante, em forma aproximada de "M"; constituída por pontos grossos, exceto nos 2/3 látero-basais do " $\mathrm{M}$ "; demais áreas do pronoto com grânulos esparsos; pilosidade constituída por tufos de pêlos dourados entre o desenho brilhante e próximo aos espinhos dos ângulos posteriores. Prosterno com grânulos pequenos esparsos e pêlos longos decumbentes. Processo prosternal reto, alongado e com ápice aguçado. Mesosterno, mesepimeros e mesepisternos com escultura igual à do prosterno, com pilosidade mais abundante e ereta. Metasterno e metepisternos com pilosidade longa e abundante. Lados do metasterno e metepisternos com pontuação muito fina e cerrada. Metasterno com pontuação grossa, rasa e anastomosada, exceto disco do metasterno, liso e glabro. Escutelo com asperezas pouco numerosas.

Élitros (Fig. 1) cerca de quatro vezes o comprimento do protórax; com tufos de pêlos dourados, dispersos e asperezas mais fortes e concentradas em torno do escutelo e gradualmente menores e mais esparsas em direção à região apical; ângulo sutural com espinho curto.

Profêmures e protíbias com asperezas e pontos mais fortes e concentrados que nos posteriores. Protarsos distintamente alongados; tarsômeros I pouco mais longos que II-III reunidos.

Abdome com pontos finos e estes, com um pêlo curto; último urosternito com pilosidade adensada e ápice chanfrado.

Dimensões (mm). Macho. Comprimento total, 21,8; maior largura do protórax (inclusive os espinhos), 6,0; menor largura do protórax (inclusive os lobos anteriores), 4,6; comprimento do protórax no centro, 4,0; largura umeral, 6,5; comprimento dos élitros, 15,5 .
Material-tipo. Holótipo macho (Fig. 1) do BRASIL, Amazonas: Itacoatiara (Estrada BR 17 - Km 23), 9.III.1958, Paul Krauss col. (MNRJ).

Discussão. Assemelha-se a S. fryi Lameere, 1912, S. sericans Tippmann, 1953 e S. sericeus Zajciw, 1970 pela abundância e comprimento dos pêlos na região dorsal do corpo e difere pela pilosidade dourada da região dorsal do corpo. Em S. fryi, $S$. sericans $\mathrm{e}$ S. sericeus a pilosidade da região dorsal é amarelada.

\section{Strongylaspis sericeus Zajciw, 1970}

(Figs. 2, 29)

Strongylaspis sericeus Zajciw, 1970: 2; Monné, 1995: 3; Júlio et al., 2000: 54 .

Descrita por Zajciw (1970) com base em duas fêmeas do Brasil (Espírito Santo). Constatou-se, através do exame destes dois exemplares, que o holótipo na realidade é um macho e o párátipo teve sua genitália removida, o que impede a confirmação do sexo. No entanto, não apresenta nenhuma diferença em relação ao holótipo, o que sugere que também seja um macho.

$S$. sericeus (Fig. 2) é semelhante a $S$. aureus, $S$. sericans e $S$. fryi. Difere da primeira pelos caracteres descritos na chave e das demais, por apresentar a pilosidade da cabeça, pronoto e pernas decumbente. Em S. sericans e $S$. fryi a pilosidade é ereta.

Dimensões (mm). Macho. Comprimento total, 21,3-27,4; maior largura do protórax (inclusive os espinhos), 6,0-7,9; menor largura do protórax (inclusive os lobos anteriores), 4,26,$0 ;$ comprimento do protórax no centro, 3,8-5,0; largura umeral, 6,3-8,6; comprimento dos élitros, 13,3-17,9.

Comprimento do holótipo e parátipo, segundo ZAJCIW (1970): 15,7-24,0.

Material-tipo. Holótipo macho e parátipo fêmea (?) de Linhares, Espírito Santo, Brasil (MNRJ).

Material examinado. BRASIL, Bahia: Jequié, 1 macho, XII.1932, Camargo col. (MZSP). Espírito Santo: Linhares (Parque Soóretama), 1 macho, I.1963, F. M. Oliveira col. (MNRJ); 1 macho, XII.1965, [sem coletor] (MNRJ); 1 macho, X.1966, [sem coletor] (MNRJ); parátipo fêmea (?), XI.1966, [sem coletor] (MNRJ); holótipo macho, XI.1967, F. M. Oliveira col. (MNRJ); 1 macho, XII.1969, sem coletor (MNRJ); 1 macho, I.1970, Maller col. (MNRJ); 1 macho, XII.1970, Maller col. (MNRJ); 1 macho, XII.1970, B. Silva col. (MNRJ); 1 macho, X.1976, B. Silva col. (MNRJ); Pedro Canário (Conceição da Barra), 2 machos, XI.1972, B. Silva col. (MZSP).

Strongylaspis fryi Lameere, 1912

(Fig. 3)

Strongylaspis fryi Lameere, 1912:133; 1915: 283; Tippmann, 1953: 187, pl.13, fig. 5; Monné, 1995: 3 (cat.).

Strongylaspis (Strongylaspis) frevi[sic]; Zajciw, 1970: 2 (nota).

Não examinada. Apresentamos uma redescrição com base em observações no diapositivo do holótipo.

Fêmea. Colorido geral do tegumento castanho-escuro, mais claro nos élitros. Pilosidade amarelada. Cabeça com abundante pilosidade, ereta e decumbente. Tubérculos anteníferos 
salientes. Lobos oculares superiores afastados. Antenas ultrapassando o meio dos élitros; escapo pontuado e com comprimento subigual ao do antenômero III e este aproximadamente um quarto menor do que os IV-V reunidos; XI pouco mais longo do que o X. Pronoto com desenho do tegumento brilhante, em forma de "Y", nitidamente destacado, com pontos grossos; demais áreas do pronoto com grânulos esparsos e pêlos eretos, longos e abundantes. Élitros com grânulos pequenos em toda extensão; pubescência concentrada em tufos em algumas áreas, rala até ausente; a cada lado do escutelo com carena proeminente; espinho do ápice sutural largo na base e dirigido para fora. Fêmures e tíbias com pêlos longos.

Material-tipo. Holótipo fêmea do Brasil (BMNH), estudado através de diapositivo feito por J. S. Moure.

Discussão. Tippmann (1953) apresentou figura de um espécime proveniente do Brasil (Mato Grosso), que julgou ser $S$. fryi, mas que na verdade nos parece ser $S$. aureus sp. nov., descrita neste trabalho.

S. fryi assemelha-se a $S$. sericeus e $S$. sericans por apresentar os élitros com pilosidade contrastante em relação ao tegumento. Difere de ambas pelo pronoto com desenho do tegumento brilhante e bem destacado, pelo espinho do ápice sutural dos élitros mais desenvolvido e pelos fêmures e tíbias com pêlos longos. Em S. sericeus e $S$. sericans o pronoto não apresenta desenho brilhante, os espinhos dos ápices dos élitros são pouco aparentes e os fêmures e tíbias apresentam pêlos curtos.

\section{Strongylaspis hirticollis Tippmann, 1953}

(Figs. 5, 28)

Strongylaspis hirticollis Tippmann, 1953: 183, pl.13, fig. 2; Monné, 1995: 3 (cat.); Martínez, 2000: 85.

Acrescentamos à descrição original: região posterior dos olhos com grânulos finos e cerrados; submento deprimido, com pontos grandes e anastomosados, a borda anterior estreita e fortemente elevada; genas separadas do submento por carena estreita e nítida; ápice genal pouco projetado e obtuso; escapo não atingindo a borda posterior dos olhos; pronoto (Fig. 5) com uma calosidade forte de cada lado da linha mediana, junto à borda posterior.

O exemplar examinado, que sem dúvida pertence a esta espécie, difere do holótipo: escapo subigual em comprimento ao antenômero III; área dos élitros em torno do escutelo com asperezas muito concentradas; último urosternito com margem posterior com reentrância mediana.

Dimensões (mm). Fêmea. Comprimento total, 32,0; maior largura do protórax (inclusive os espinhos posteriores) 8,8; menor largura do protórax (ângulos anteriores), 4,1; comprimento do protórax no centro, 4,8; largura umeral, 8,7; comprimento dos élitros, 23,1.

Material-tipo. Holótipo fêmea de Santa Fe de Bogotá, Cundinamarca, Colômbia (USNM), estudado através de diapositivo feito por J. S. Moure.
Discussão. S. hirticollis e S. sericans Tippmann, 1953 assemelham-se pelo pronoto com desenho do tegumento pouco ou não-destacado, constituído por tubérculos e saliências dispersas. S. hirticollis difere de $S$. sericans, além dos caracteres descritos na chave, pela pubescência elitral mais esparsa e pelos grânulos elitrais mais uniformemente distribuídos. $\operatorname{Em} S$. sericans, a pubescência elitral é mais densa e os grânulos elitrais mais esparsos em direção ao ápice.

Material examinado. COLÔMBIA, Cundinamarca: Fusagasugá, 1 fêmea, 18.IX.1921, P. Apolinar col. (MZSP).

Strongylaspis sericans Tippmann, 1953

(Figs. 4, 28)

Strongylaspis sericans Tippmann, 1953: 184, pl. 13, fig. 3; Zajciw, 1970: 2 (nota); Monné, 1995: 3 (cat.); Martínez, 2000: 85.

Acrescentamos à descrição original: submento subdeprimido, com pontuação completamente anastomosada; genas separadas do submento por carena fina e pouco desenvolvida; escapo atingindo a borda posterior dos olhos; antenômero XI engrossado; pilosidade das antenas conspícua até o antenômero VIII; desenho do tegumento do pronoto formado por dois tubérculos localizados ao lado da linha mediana (no centro do disco), seguidos por uma calosidade central elevada e afilada em direção à borda posterior, na extremidade da qual com uma depressão circular pequena; pronoto com linha mediana saliente no terço anterior, carena longitudinal larga e irregular de cada lado do disco pronotal e um tubérculo de cada lado do terço médio; grânulos elitrais em torno do escutelo, ásperos; élitros, de cada lado do escutelo, com carena curta, proeminente.

Dimensões (mm). Macho. Comprimento total, 20,0; maior largura do protórax (inclusive os espinhos posteriores), 6,1; menor largura do protórax (ângulos anteriores), 4,1; comprimento do protórax no centro, 3,4; largura umeral, 6,2; comprimento dos élitros, 13,5.

Material-tipo. Holótipo macho e parátipo fêmea de arredores de Bogotá, Cundinamarca, Colômbia (USNM). Holótipo estudado através de diapositivo feito por J. S. Moure.

Discussão. Vide comentários em S. sericeus, S. fryi e $S$. hirticollis.

Material examinado. COLÔMBIA, Tolima: Rio Chili, 1 macho, 4.VI.1915, P. Apolinar col. (MZSP).

\section{Strongylaspis graniger Bates, 1884}

\section{(Fig. 17)}

Strongylaspis graniger Bates, 1884: 233; Monné, 1995: 3 (cat.). Strongylaspis (Strongylaspis) granigera[sic]; Lameere, 1903: 31. Strongylaspis granigera[sic]; Chemsak et al., 1992: 16.

LAMEERE (1903) apresentou uma redescrição que permite identificar a espécie com facilidade. No entanto, o desenho brilhante do tegumento pronoto (Fig. 17), em forma de "X", 
não é em grande parte liso como afirmou esse autor, mas sim com grânulos salientes na parte anterior do desenho e pontos esparsos na posterior. A espécie foi descrita com base em único macho. LAMEeRE (l.c.) disse: “je n'ai vu que le mâle, type unique, conservé au British Museum”. Mas na chave apresentada no mesmo trabalho, afirmou: "Antennes n'atteignant pas le tiers postérieur des élytres chez la femelle,...". Fica claro que houve equivoco na inclusão de caracteres da fêmea na referida chave.

Assemelha-se a $S$. corticarius (Erichson, 1848) pela aparência geral e difere principalmente, por apresentar élitros com grânulos em toda extensão. Em $S$. corticarius os grânulos ocorrem apenas na metade anterior dos élitros.

Material-tipo. Holótipo macho do Panamá (BMNH), examinado através de fotografia realizada pelo Dr. Frank Hovore e diapositivo feito por J. S. Moure.

\section{Strongylaspis bolivianus sp. nov.}

(Figs. 7, 29)

\section{Etimologia. Relativa ao país de origem.}

Fêmea. Colorido geral do tegumento castanho-escuro. Élitros de cor avelã, exceto região circum-escutelar, região sutural e epipleuras, escurecidas. Pilosidade geral amarelada. Cabeça fortemente deprimida entre os lobos oculares superiores; com pontos grossos e anastomosados; pilosidade longa, esparsa e dirigida para região anterior. Tubérculos anteníferos proeminentes e pontuado-pubescentes (pontos menores e mais rasos em direção à base do escapo). Região posterior dos olhos pontuado-estriada, com pêlos eretos, mais concentrados junto à borda dos olhos. Carena ocular inconspícua. Olhos nitidamente desenvolvidos; distância entre os lobos superiores muito menor do que entre os lóbulos inferiores. Fronte grosseiramente pontuada e com pilosidade esparsa. Sutura epistomal indistinta. Sutura coronal pouco aparente. Clípeo rugoso e com pêlos longos. Labro com pontos pequenos cerrados; pilosidade abundante em forma de densa escova na borda anterior. Genas com raros pontos grossos e pêlos na região lateral; região ventral com pontos pequenos, abundantes e pêlos mais numerosos que nas laterais. Submento pontuado-rugoso com pilosidade ereta e esparsa; borda anterior fortemente elevada, lisa e com alguns pêlos. Gula brilhante, com pêlos esparsos, com raros pontos rasos junto ao submento e estriada entre as fossas tentoriais. Dorso das mandíbulas com pontos finos e confluentes e pilosidade longa que acompanha o eixo longitudinal das mandíbulas; borda interna e ápice, lisos e glabros; região ventral com pontos mais rasos e pubescência esparsa. Antenas (Fig. 7) atingindo aproximadamente o meio dos élitros; escapo mais longo do que o antenômero III, com pontuação cerrada e pêlos bem visíveis, principalmente nos $2 / 3$ basais, fracamente curvado; III com $2 / 3$ do comprimento dos IV-V reunidos, pontuado e com pêlos curtos no dorso e $2 / 3$ ventro-basais, e estriado no terço ventro-apical; III-IV com carena no terço ventro-apical; IV-VI com pontos rasos, pêlos curtos e esparsos e estrias mais evidentes na região ventral; VII-XI inteiramente estriados; VXI com carena completa no lado ventral, mais elevada em direção aos ápices.

Protórax (Fig. 7) com ângulos anteriores não-projetados; ângulos posteriores com espinho agudo, inclinado para cima quase em ângulo reto. Tegumento do pronoto sem desenho brilhante, com pontos grandes anastomosados em toda a extensão, exceto no terço centro-apical, com pontos menores e esparsos; região centro-anterior com depressão rasa longitudinal; pilosidade longa e abundante; borda anterior ligeiramente côncava e borda posterior convexa. Prosterno, proepisternos, mesosterno, mesepimeros e mesepisternos com pontos finos e esparsos e pêlos moderadamente abundantes. Processo prosternal fortemente curvado, com fileira de pêlos esparsos no disco e em forma de escova nas bordas. Metasterno e metepisternos com pontos pequenos cerrados e pilosidade conspícua. Escutelo com pêlos curtos esparsos e asperezas pequenas e numerosas.

Élitros cerca de cinco vezes o comprimento do protórax; com asperezas fortes e concentradas em torno do escutelo, gradualmente menores e mais esparsas em direção ao ápice; cada aspereza com um pêlo curto; úmeros sem saliências; ângulo sutural inerme.

Fêmures com pêlos e pontos esparsos (mais densos nos profêmures). Tíbias pontuadas, pubescentes, adensadas na face ventral. Trocanteres com pilosidade evidente. Pro- e mesotarsômeros I pouco menores que os dois seguintes reunidos; metatarsômero I tão longo quanto os dois seguintes reunidos.

Urosternitos brilhantes, com pontos esparsos e pilosidade curta, pouco concentrada. Último urosternito com margem arredondada.

Dimensões (mm). Fêmea. Comprimento total, 36,4; maior largura do protórax (inclusive os espinhos posteriores), 9,6; menor largura do protórax (ângulos anteriores), 5,2; comprimento do protórax no centro, 5,1; largura umeral, 10,2; comprimento dos élitros, 27,8 .

Material-tipo. Holótipo fêmea (Fig. 7) de BOLÍVIA, La Paz: Nor Yungas, X.1990, P. Bleuzen col. (MZSP).

Discussão. Entre as espécies que apresentam os élitros glabros ou com pilosidade pouco aparente, S. bolivianus $\mathbf{s p}$. nov. assemelha-se a $S$. championi Bates, 1884 pelo pronoto com pêlos longos e evidentes; difere pelos caracteres descritos na chave.

\section{Strongylaspis championi Bates, 1884}

(Figs. 6, 28)

Strongylaspis championi Bates, 1884: 233; Zajciw, 1970: 3; Monné, 1995: 2 (cat.). Strongylaspis (Strongylaspis) Championi [sic]; Lameere, 1903: 29.

Fêmea. Colorido geral do tegumento castanho-escuro. Pilosidade geral amarelada. Cabeça ligeiramente deprimida entre os lobos oculares superiores; com grânulos e pontos 

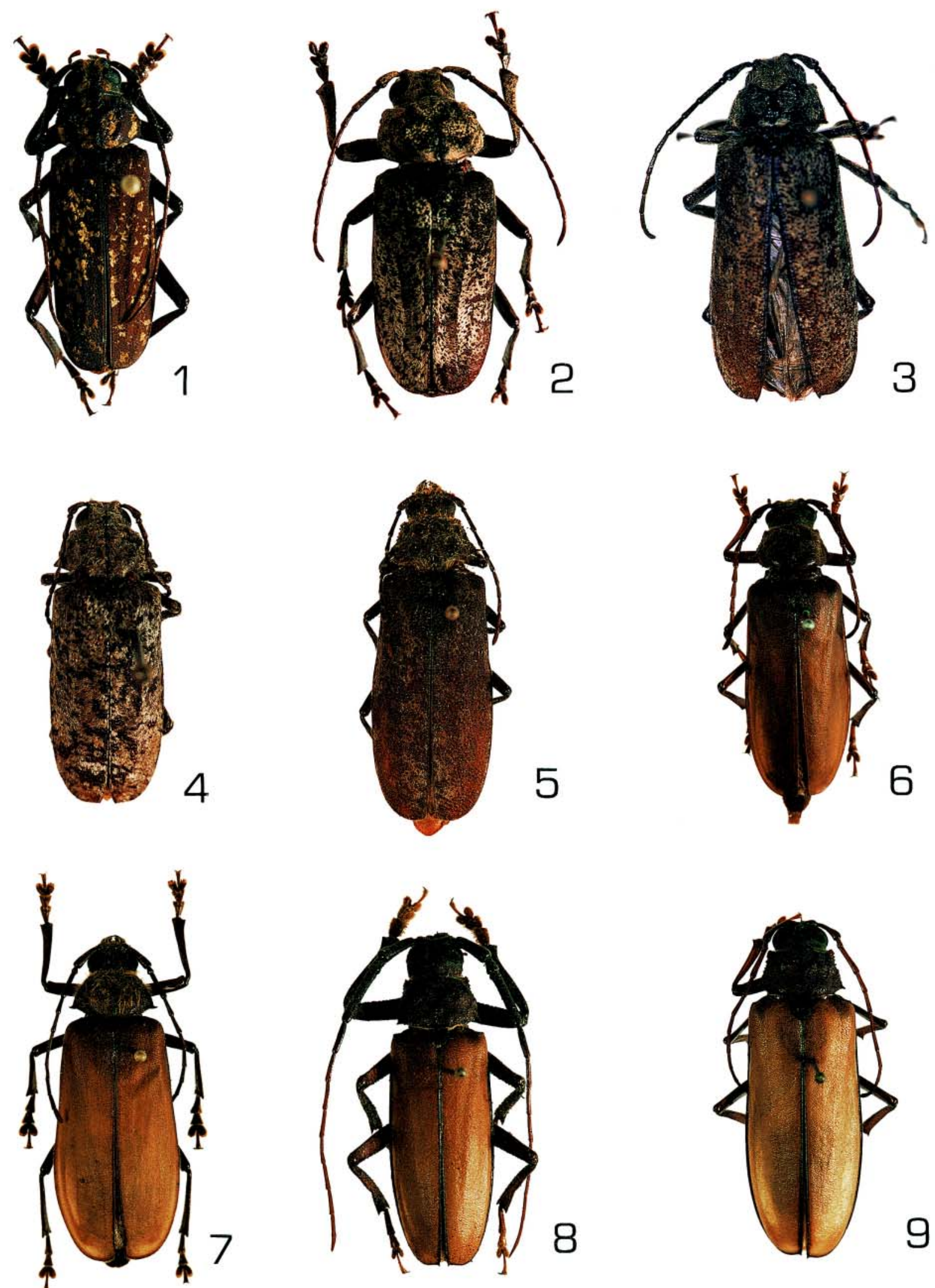

Figs. 1-9. 1, Strongylaspis aureus sp. nov. (holótipo macho); 2, S. sericeus Zajciw, 1970 (macho); 3, S. fryi Lameere, 1912 (holótipo fêmea), reproduzida do diapositivo feito por J. S. Moure no BMNH; 4, S. sericans Tippmann, 1953 (macho); 5, S. hirticollis Tippmann, 1953 (fêmea); 6, S. championi Bates, 1884 (fêmea); 7, S. bolivianus sp. nov. (holótipo fêmea); 8, S. migueli sp. nov. (holótipo macho); 9, S. migueli sp. nov. (parátipo fêmea). 
confluentes; pilosidade longa e esparsa (mais longa e concentrada na fronte e clípeo). Tubérculos anteníferos com pontos finos e esparsos próximo ao escapo. Sutura coronal saliente no vértice. Região posterior dos olhos com grânulos esparsos e pêlos curtos; borda infero-posterior dos olhos com franja rala de pêlos. Carena ocular conspícua e larga. Distância dos lobos oculares superiores cerca do dobro da largura de um lobo. Sutura epistomal indistinta. Labro com pilosidade longa. Genas grosseiramente pontuadas e com pilosidade curta; ápices obtusos, pouco destacados. Submento deprimido, com pontos grossos, rasos e confluentes e pêlos esparsos; borda anterior elevada, estriada transversalmente e com pêlos esparsos. Gula mais elevada que o submento, com estrias transversais e pêlos curtos e esparsos. Antenas apenas alcançando o meio dos élitros; escapo atingindo a borda posterior dos olhos, com pontos finos não-confluentes e raros pêlos longos no terço infero-basal; pedicelo com pontuação igual à do escapo; face ventral com franja de pêlos curtos na base e raros pêlos mais longos no terço apical; antenômero III com aproximadamente $3 / 4$ do comprimento dos IV-V reunidos; lado ventral com pontos finos e confluentes no terço basal, esparsos no terço médio e estriado no terço apical; IV-VIII com escultura formada por pontos e estrias (as estrias gradativamente revestindo uma área maior do antenômero IV para o VIII); IX-XI inteiramente estriados; XI pouco maior do que o X.

Bordas laterais do protórax com crenulado fraco; ângulos anteriores projetados; ângulos posteriores com espinho longo voltado para cima. Escultura do pronoto formada por duas saliências longitudinais na região anterior do disco, brilhantes e com pontos esparsos, entre as quais há uma depressão elíptica transversal, dividida no centro por uma carena tênue e fina; terço médio do disco com uma calosidade elevada; margem posterior com depressão mediana; a cada lado do desenho brilhante, com uma saliência pequena, pontuada; demais áreas com pontos grossos anastomosados, exceto na borda posterior, com pontos finos não-confluentes; pilosidade longa (maior e mais cerrada nas laterais). Processo prosternal fortemente curvado, bordas laterais elevadas e ápice arredondado; pilosidade longa e densa. Esternos torácicos com pilosidade longa e abundante. Metasterno e metepisternos com pontos pequenos cerrados (menores em direção ao centro do disco metasternal). Escutelo com asperezas pequenas e pouco numerosas.

Élitros cerca de cinco vezes o comprimento do protórax; com asperezas e pêlos curtos próximo ao escutelo; demais regiões com pontos rasos (quase imperceptíveis no terço apical) e glabros; úmeros sem saliências; espinhos dos ângulos suturais bem visíveis (paralelos no exemplar examinado e convergentes no lectótipo examinado por meio de diapositivo).

Fêmures e tíbias com pontuação rasa e fina. Metatarsômero I pouco mais longo que II-III reunidos.

Urosternitos brilhantes, com pontuação microscópica esparsa e alguns pêlos curtos no centro; pêlos mais longos e pontuação mais concentrada aos lados; último urosternito com forte reentrância mediana na margem apical.

Dimensões (mm). Fêmea. Comprimento total, 36,0; maior largura do protórax (inclusive os espinhos), 9,3; menor largura do protórax (inclusive os lobos anteriores), 5,6; comprimento do protórax no centro, 5,1; largura umeral, 9,9; comprimento dos élitros, 24,7.

Material-tipo. Espécie descrita com base em um número não especificado de machos e fềmeas (BATEs 1884). Lectótipo fềmea designado por Chemsak \& Linsley (1970) de Cerro Zunil, Quezaltenango, Guatemala $(\mathrm{BMNH})$ e estudado através de fotografia realizada pelo Dr. Frank Hovore e pelo diapositivo feito por J. S. Moure.

Material examinado. COSTA RICA, 1 fêmea, [sem data], J. P. Marechal col. (MNRJ).

\section{Strongylaspis migueli sp. nov.} (Figs. 8, 9, 29)

Etimologia. Homenagem ao Dr. Miguel A. Monné, por sua valiosa contribuição ao conhecimento de Cerambycidae e, em particular, a este trabalho.

Macho. Colorido geral do tegumento castanho; élitros de cor avelã exceto epipleuras, sutura e espinhos castanhoescuros a pretos. Pilosidade amarelada. Vértice sulcado longitudinalmente (mais profundamente entre os tubérculos anteníferos), com pequenas asperezas com um pêlo microscópico. Tubérculos anteníferos com pontos grossos e anastomosados na base e pontos finos e esparsos junto ao escapo. Região posterior dos olhos com diminutos grânulos cerrados e superfície microesculturada. Carenas oculares pouco elevadas e restritas aos ápices dos lobos superiores. Olhos mais distantes entre si do lado ventral do que do lado dorsal. Fronte com pontuação grossa e confluente e pêlos esparsos. Sutura epistomal indistinta. Sutura coronal enegrecida. Clípeo com superfície irregular e pilosidade mais longa que na fronte. Labro cerradamente pontuado no disco e com pêlos longos. Genas com pontos rasos junto à fóvea antenal e mais profundos em direção ao lado ventral; pilosidade microscópica e esparsa; ápices pouco projetados e obtusos. Submento com pêlos esparsos, pouco deprimido, superfície microesculturada e com diversas asperezas pequenas; margem anterior pouco elevada, lisa ou com estrias transversais pequenas e esparsas. Limite entre gula e submento indistinto. Região dorsal das mandíbulas com pontos oblongos confluentes e pêlos dirigidos para frente, exceto no ápice e borda interna. Antenas alcançando o ápice elitral; escapo com dorso áspero, principalmente nos $2 / 3$ basais e com pontos esparsos no lado ventral; pilosidade microscópica, ligeiramente mais longa no lado ventral; antenômero III tão longo quanto os IV-V reunidos, com asperezas e pontuação densas nos $2 / 3$ basais, o ápice ventral estriado; IV-VI estriados ou com pontos rasos no lado dorsal e estriados no lado ventral; VII-XI inteiramente estriados; XI aproximadamente $1 / 3$ mais longo que $X$, com intumescência suave, pouco depois do meio.

Ângulos anteriores do protórax com lobo pouco desenvolvido; ângulos posteriores com espinho dirigido obliquamente para trás; borda anterior sinuosa; borda posterior convexa. Pronoto glabro; desenho do tegumento brilhante, bem 

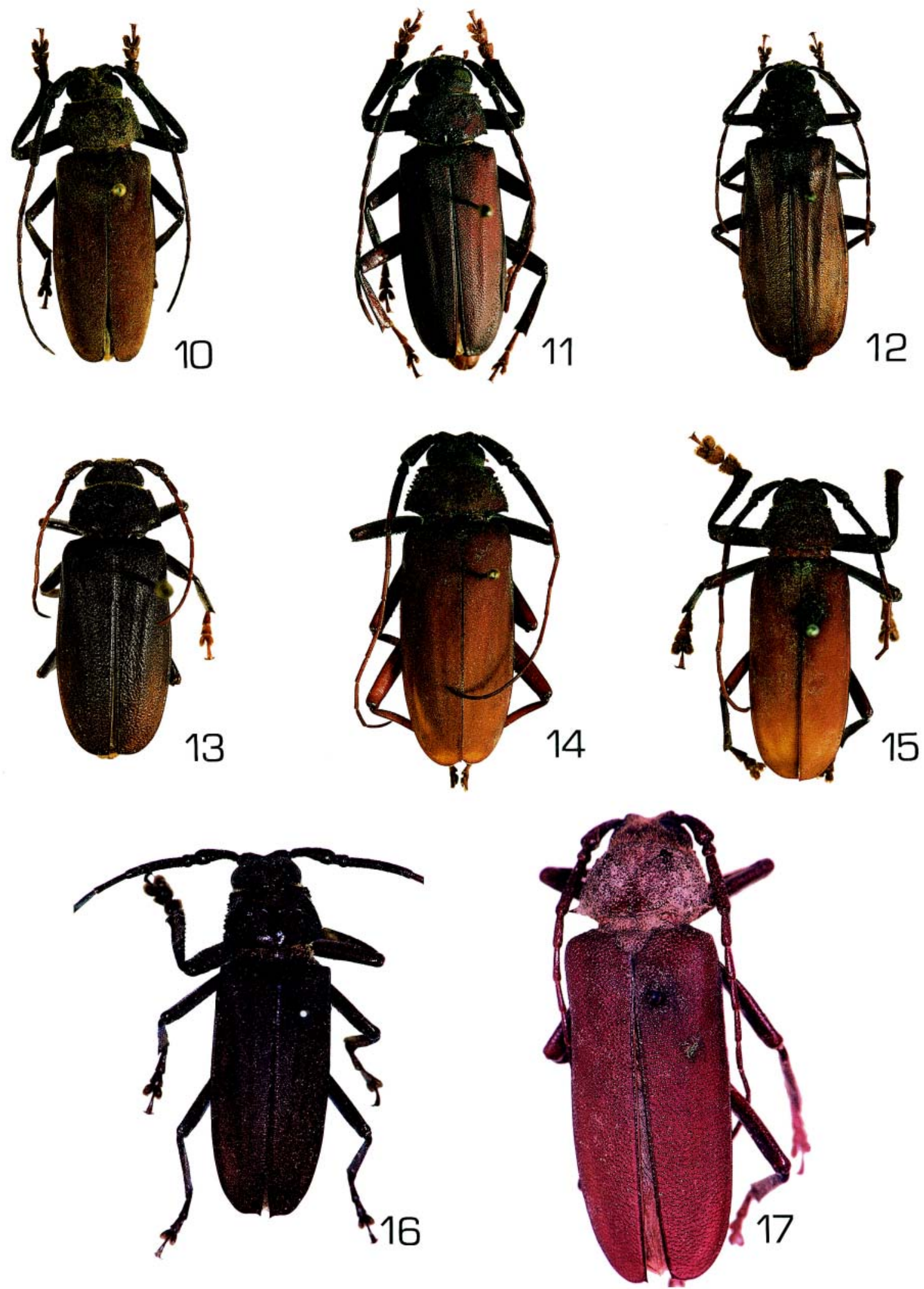

Figs. 10-17. 10, Strongylaspis bullatus Bates, 1872 (macho); 11, S. cristianae sp. nov. (holótipo macho); 12, S. kraepelini kraepelini Lameere, 1903 (fêmea); 13, S. kraepelini parvula Linsley \& Chemsak, 1966 (macho); 14, S. corticarius (Erichson, 1848) (macho); 15, S. batesi Lameere, 1903 (macho); 16, S. macrotomoides Tippmann, 1953 (holótipo macho) reproduzida do diapositivo feito por J. S. Moure no USNM; 17, S. graniger Bates, 1884 (holótipo macho) reproduzida do diapositivo feito por J. S. Moure no BMNH. 
visível, com forma aproximada de um "X" e uma saliência do lado de cada um dos ápices superiores do desenho central; superfície do desenho com pontos bem marcados; demais regiões com superfície microesculturada e asperezas pequenas. Processo prosternal sulcado longitudinalmente e com o ápice arredondado e paralelo ao corpo; margens enegrecidas e com escova de pêlos curtos. Proepisternos e prosterno glabros, com pequenos grânulos brilhantes e fundo mate. Mesosterno, mesepisternos e mesepimeros com diminutos grânulos e pêlos curtos e abundantes. Lados e região anterior do metasterno com grânulos pequenos cerrados; disco metasternal com pontos rasos concentrados; pilosidade do metasterno longa e abundante. Metepisternos com escultura e pilosidade iguais às dos lados do metasterno. Escutelo com diversas asperezas pequenas e pêlos microscópicos.

Élitros cerca de quatro vezes o comprimento do protórax; com asperezas bem visíveis e concentradas em torno do escutelo e dispersas em direção ao terço posterior, gradativamente substituídas por pontuação rasa e confluente; úmeros com saliência obtusa; ângulo sutural com espinho bem visível e inclinado para dentro.

Pernas anteriores notavelmente mais robustas que as demais. Meso- e metafêmures pontuados aos lados (ásperos nas bordas infero-laterais de alguns exemplares). Protíbias ásperas e com espinhos curtos e escova bem visível na metade ventro-apical. Meso- e metatíbias pontuadas e com escova de pêlos do lado ventral menos conspícua. Protarsos, fortemente alargados; proe mesotarsômero I pouco mais curtos que II-III reunidos. Metatarsômero I tão longo ou pouco mais longo que os dois seguintes reunidos.

Abdome brilhante, com pontos rasos e pêlos não concentrados (alguns exemplares apresentam também alguns grânulos dispersos); último urosternito com ápice chanfrado e pilosidade mais longa e concentrada.

Fêmea (Fig. 9). Antenas apenas ultrapassando o meio dos élitros; desenho brilhante do tegumento do pronoto menos distinto; escultura do pronoto formada por pontos grossos anastomosados; escapo cerca de $2 / 3$ do comprimento do III e apenas pontuado; antenômero III subigual ao IV-V reunidos; élitros cerca de cinco vezes o comprimento do protórax e com asperezas mais esparsas e espinhos dos ápices suturais subretos e menores; pernas anteriores subiguais às demais; profêmures e protíbias fracamente ásperas; último urosternito mais brilhante e com pêlos apenas nas bordas.

Dimensões (mm). Macho/fêmea. Comprimento total, 21,1$35,7 / 26,0-36,8$; maior largura do protórax (inclusive os espinhos), 5,4-8,6/5,9-8,3; menor largura do protórax (inclusive os lobos anteriores), 4,4-6,3/4,5-6,3; comprimento do protórax no centro, 3,6-5,6/3,8-5,1; largura umeral, 5,6-9,8/7,0-10,0; comprimento dos élitros, 15,1-24,7/19,5-26,8.

Material-tipo. Holótipo macho (Fig. 8) do BRASIL, Mato Grosso: Diamantino (Alto Rio Arinos), X.1983, B. Silva col. (MNRJ). Parátipos - BRASIL, Rondônia: Ouro Preto do Oeste, 1 macho, XI.1983, Becker, Roppa e Silva col. (MNRJ); Pará: Óbidos, 1 fêmea, 9.X.1957, F. M. Oliveira col. (MNRJ). Maranhão: Imperatriz, 1 macho, XI.1998, L. F. Reys col. (MNRJ); Mato Grosso: Barra do Bugres, 1 macho, X.1984, B.
Silva col. (MZSP); Cáceres, 1 macho, X.1973, [sem coletor] (MNRJ); Rosário Oeste, 1 fêmea, X.1968, [sem coletor] (MNRJ); 1 fêmea, XII.1968, [sem coletor] (MNRJ); 1 fêmea, XII.1969, [sem coletor] (MZSP); 1 fêmea, II.1970, Maller col. (MNRJ); 1 macho, XII.1970, [sem coletor] (MNRJ). Espírito Santo: Colatina, 1 fêmea, XI.1965, [sem coletor] (MNRJ).

Discussão. Difere das demais espécies do gênero por apresentar os élitros de coloração avelã e nitidamente contrastantes com o colorido castanho-escuro a preto das epipleuras, sutura e espinhos suturais.

\section{Strongylaspis bullatus Bates, 1872}

$$
\text { (Figs. 10, 28) }
$$

Strongylaspis bullatus Bates, 1872: 167; Chemsak et al., 1992: 16; Monné, 1995: 2 (cat.).

Strongylaspis (Strongylaspis) bullata[sic]; Lameere, 1903: 33.

Macho. Colorido geral do tegumento castanho; pernas e antenas castanho-escuras. Pilosidade geral amarelada. Cabeça com pilosidade conspícua, decumbente, mais concentrada entre os lobos superiores dos olhos; escultura formada por grânulos pequenos, brilhantes e esparsos, mais cerrados nos tubérculos anteníferos (exceto borda dos tubérculos anteníferos, junto ao escapo, com pontos moderadamente densos). Região posterior dos olhos com grânulos cerrados e pubescência distinta. Carena ocular nítida. Distância entre os lobos oculares superiores pouco maior que a largura de um lobo. Sutura epistomal indistinta. Sutura coronal enegrecida, estreita e bem marcada. Clípeo com pontuação grossa e anastomosada e pêlos longos e esparsos. Labro com pêlos longos e abundantes. Genas com pontos rasos anastomosados e pêlos curtos; ápices arredondados e pouco projetados. Submento deprimido, com diversos grânulos pequenos e pêlos mais longos e mais concentrados nas laterais; borda anterior elevada, estreita, glabra e com estrias transversais rasas. Limite entre submento e gula distinto nas laterais, pouco marcado no centro. Mandíbulas, no dorso e face lateral externa, com pontos grossos anastomosados e pêlos longos decumbentes; ápice liso e glabro. Antenas atingindo o ápice elitral; escapo, pedicelo e antenômero III fortemente ásperos e com raros pêlos microscópicos; escapo com metade do comprimento do antenômero III e este aproximadamente $1 / 4$ maior do que os IVV reunidos; IV-XI inteiramente estriados; XI cerca de 1,5 vezes o comprimento do $\mathrm{X}$ e com intumescência após o meio.

Protórax com ângulos anteriores pouco salientes; ângulos posteriores com espinho pouco projetado. Pronoto com pubescência abundante e grânulos pequenos cerrados; tegumento brilhante, com duas saliências longitudinais, localizadas na metade anterior, subparalelas, entre as quais há uma depressão transversal, e aos lados delas, na direção da base, duas saliências pequenas, também brilhantes. Prosterno, processo prosternal e proepisternos com grânulos pequenos esparsos e pêlos curtos. Processo prosternal com bordas enegrecidas e salientes. Mesosterno, mesepisternos e mesepimeros com grânulos menores e mais esparsos do que no prosterno e pilosidade mais longa e abundante. Processo 

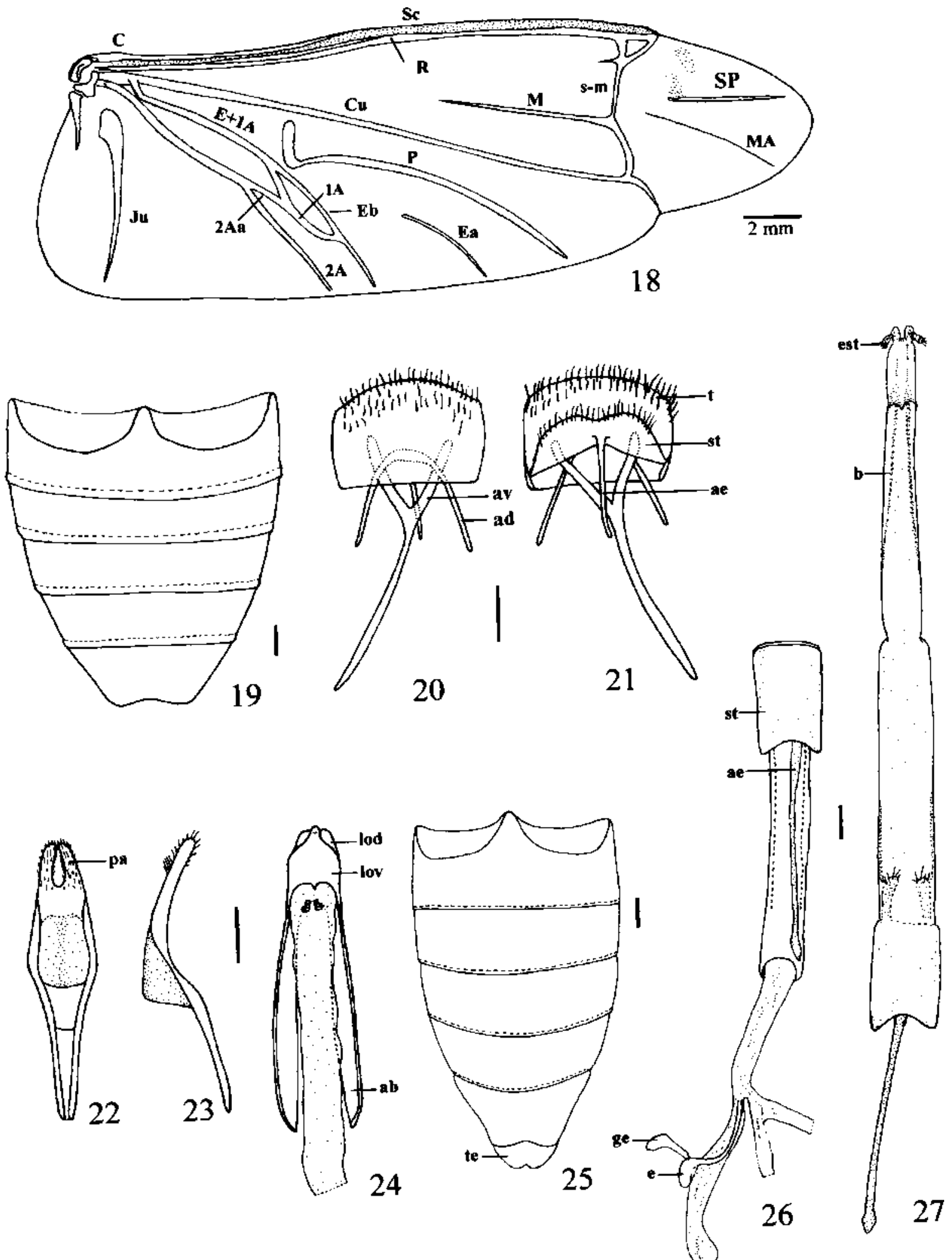

Figs. 18-27, Strongylaspis corticarius. Macho: 18, asa; 19, abdome; 20, oitavo e nono segmentos, vista ventral; 21, idem, vista dorsal; 22, tégmen, vista ventral; 23, idem, vista lateral; 24, lobo médio. Fêmea: 25, abdome; 26, terminália invertida; 27, terminália evertida. Ab = apófise basal; ad = arco dorsal; $\mathrm{ae}=$ apófise esternal; $\mathrm{av}=\operatorname{arco}$ ventral $; \mathrm{b}=$ baculi $; \mathrm{C}=\mathrm{Costa} ; \mathrm{Cu}=$ Cubital; $\mathrm{e}=$ espermateca; $\mathrm{E}=\mathrm{Empusal} ; \mathrm{Ea}=\mathrm{ramo}$ a da Empusal; Eb $=$ Empusal b; est $=$ estilo; ge = glândula da espermateca; Ju = Jugal; lod = lobo dorsal; lov = lobo ventral; $\mathrm{M}=$ Média; MA = Média-Anterior; $\mathrm{P}=\mathrm{Plical}$; $\mathrm{pa}=$ parâmero; $\mathrm{R}=$ Radial; $\mathrm{Sc}=$ Subcosta; $\mathrm{s}-\mathrm{m}=$ transversa setor-média; $\mathrm{SP}=$ Setor-Posterior; $\mathrm{st}=$ urosternito VIII; $\mathrm{t}=$ urotergito VIII; te $=$ tergito VII; $1 \mathrm{~A}=1^{\mathrm{a}}$ anal; $2 \mathrm{~A}=2^{\mathrm{a}}$ anal; $2 \mathrm{Aa}=$ ramo da $2 \mathrm{~A}$. Barra $=1 \mathrm{~mm}$. 
mesosternal fortemente canaliculado longitudinalmente e com ápice chanfrado; pubescência em forma de escova moderadamente forte nas bordas. Lados do metasterno e metepisternos com grânulos microscópicos cerrados e pilosidade densa e curta; centro do disco metasternal com pontos diminutos concentrados e pubescência muito rala. Escutelo com asperezas pouco numerosas e fortes, com um pêlo curto.

Élitros cerca de quatro vezes o comprimento do protórax; pubescentes, com asperezas fortes em torno do escutelo, gradualmente menores em direção ao ápice; úmeros inermes; ângulo sutural com espinho muito pequeno.

Pernas anteriores mais longas e robustas que as demais. Profêmures e protíbias fortemente ásperos. Metatarsômero I tão longo quanto os dois seguintes reunidos.

Abdome com fundo microesculturado, grânulos e pêlos curtos e abundantes; último urosternito com ápice chanfrado e pêlos longos em forma de escova.

Dimensões ( $\mathrm{mm}$ ). Macho. Comprimento total, 28,7; maior largura do protórax (inclusive os espinhos), 8,2; menor largura do protórax (inclusive os lobos anteriores), 6,1; comprimento do protórax no centro, 4,9; largura umeral, 8,8; comprimento dos élitros, 20,9.

Material-tipo. Holótipo macho de Nicarágua, Chontales (proximidades de Santo Domingo) (BMNH).

Discussão. Bates (1872) afirmou: “'One example in Mr. Belt's collection." e "Long. 12 lin. O’." No entanto, LameERE (1903) escreveu: "je n'ai vu que le couple type de Bates au British Museum". Portanto, a fêmea que Lameere disse ter examinado no British Museum, não era um síntipo. Bates $(l . c$. ) disse: "elytris minus parallelus elongato subellipticus". No exemplar examinado os élitros não são notavelmente alargados no meio, mas este caráter é variável e ocorre também em $S$. batesi Lameere, 1903. S. bullatus é semelhante à $S$. corticarius e $S$. championi; difere principalmente pelas asperezas do escutelo, que são maiores e em menor quantidade.

Material examinado. MÉXICO, Guerrero: Acapulco, 1 macho, 25.VII.1953, F. Bonet col. (MNRJ).

\section{Strongylaspis christianae sp. nov.}

(Figs. 11, 29)

Etimologia. A espécie é dedicada a Christiana Klingenberg, pelas traduções do alemão para o português, utilizadas neste e em outros trabalhos.

Macho. Colorido geral do tegumento castanho; cabeça, protórax, antenômeros I-IV e pernas mais escuras. Pilosidade geral amarelada. Vértice com pontuação grossa, cerrada e confluente (os pontos maiores e mais profundos em direção à fronte), sulcado longitudinalmente e com raros pêlos microscópicos. Tubérculos anteníferos com pontos confluentes (menores próximo à base do escapo). Região posterior dos olhos com saliências pequenas e cerradas. Carena ocular não elevada, estreita, enegrecida, inicia no tubérculo antenífero e termina junto à borda póstero-superior dos olhos. Olhos pequenos; distância entre os ápices dos lobos inferiores maior do que entre os ápices dos lobos superiores. Fronte com pontos grossos anastomosados e pêlos curtos esparsos. Sutura epistomal ausente. Sutura coronal enegrecida, pouco distinta próximo à fronte. Clípeo com pontuação confluente mais fina $\mathrm{e}$ pêlos maiores e mais concentrados do que na fronte. Labro com pontos rasos e pêlos longos e abundantes. Genas com pontos finos e pilosidade microscópica esparsa; ápices obtusos, pouco projetados. Submento deprimido com grânulos esparsos, fundo mate e raros pêlos longos; margem anterior elevada, transversalmente estriada e precedida por sulco raso. Mandíbulas pontuado-pubescentes na região dorsal, exceto ápice e margem interna, lisos e glabros; região ventral com pontos finos e não concentrados e raros pêlos curtos. Antenas atingindo o quarto apical dos élitros; escapo atingindo a borda anterior do protórax, ligeiramente curvado para dentro e achatado dorso-ventralmente nos 3/4 basais; escultura dorsal formada por pontos finos e confluentes, principalmente nos $2 /$ 3 basais, e raros pêlos microscópicos; escultura ventral constituída por pontos menos concentrados; antenômero III $1 / 6$ mais longo que o escapo e 1/3 mais longo que o IV; III-VII pontuados no dorso; VIII dorsalmente pontuado nos $2 / 3$ basais e estriado no terço apical; IX-XI inteiramente estriados dorsalmente; ápice ventral do III, 2/3 apicais do IV e dos V-VIII, estriados; $2 / 3$ basais do antenômero III, $1 / 3$ basal do antenômero IV com pontos esparsos; III-X com carena suave no lado ventral, mais elevada em direção aos ápices; XI com pêlos curtos no ápice.

Ângulos anteriores do protórax com lobo pouco desenvolvido, projetado para frente; ângulos posteriores com espinho voltado para trás e para cima; borda anterior sinuosa. Pronoto com desenho do tegumento distinto, formado anteriormente por calosidades enegrecidas, unidas no centro a uma placa triangular brilhante com início, aproximadamente, no centro do disco pronotal e terminando na borda posterior; toda a área do pronoto com asperezas esparsas, exceto na região em torno da placa triangular, apenas pontuada; pubescência esparsa. Proepisternos e prosterno com asperezas difusas e pontos rasos. Processo prosternal com pontos rasos e esparsos. Mesosterno, mesepimeros e mesepisternos com asperezas e pilosidade bem visíveis. Metasterno com abundantes pêlos longos e pequenas asperezas diminuindo de tamanho em direção ao centro do disco metasternal; faixa central glabra. Metepisternos com asperezas mais concentradas que no metasterno e igualmente pilosos. Escutelo pouco convexo, com asperezas pequenas e relativamente numerosas; pêlos curtos e esparsos.

Élitros cerca de quatro vezes o comprimento do protórax; paralelos na base, levemente alargados até o terço apical onde se estreitam; cada élitro com três carenas com início próximo à base e terminando no terço apical e uma outra, apenas indicada, no terço mediano; escultura formada por asperezas maiores e mais cerradas em torno do escutelo, gradualmente reduzidas em tamanho e concentração em direção ao terço apical e 


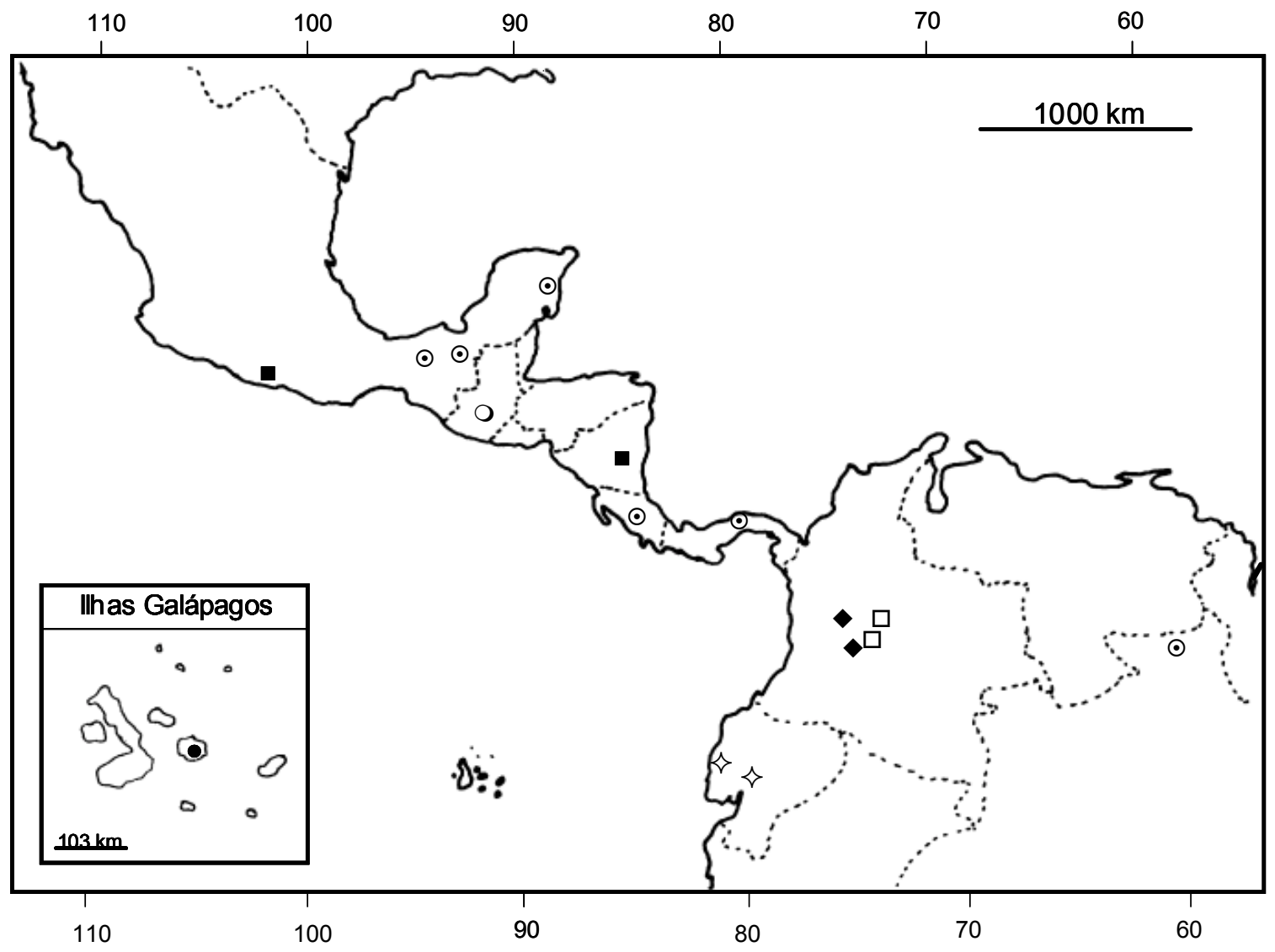

Fig. 28. Distribuição geográfica de Strongylaspis bullatus $(\square)$, S. corticarius $(\odot)$, S. championi $(\bigcirc)$, S. sericans $(\diamond)$, S. hirticollis $(\square)$, S. kraepelini kraepelini (ઐ), S. kraepelini parvula $(\bullet)$.

substituídas por pontos rasos e confluentes; pubescência esparsa e microscópica, restrita à área em torno do escutelo e epipleuras; úmeros com curta projeção obtusa enegrecida; ângulo sutural inerme ou apenas saliente.

Profêmures ásperos (mais suavemente na face ventral); mesofêmures pontuados; metafêmures quase lisos no terço basal, e pontuados nos $2 / 3$ apicais. Tíbias com pontuação forte na face externa (principalmente as protíbias) e mais fraca na face interna; com franja de pêlos nos $2 / 3$ apicais da borda inferior e pêlos esparsos nas faces interna e externa; protíbias mais robustas que as demais. Protarsômero alargado; mesotarsômero I tão longo quanto os dois seguintes reunidos; metatarsômero I pouco mais longo que II-III reunidos.

Urosternitos brilhantes; I-IV quase glabros e com pontos finos; último urosternito com reentrância no ápice e pilosidade abundante no terço apical.

Fêmea. Antenas alcançando o terço apical dos élitros; escapo alcançando a borda posterior dos olhos, mais delgado e fracamente pontuado; antenômero III $1 / 4$ mais longo que o escapo; prosterno e proepisternos com asperezas mais difusas e pontuação quase nula, com fundo microesculturado; pronoto com asperezas numerosas e cerradas; escutelo mais plano; élitros cerca de cinco vezes o comprimento do protórax; profêmures mais finamente esculturados; protíbias não robustas; protarsômeros não alargados; urosternitos com pontuação mais fina; último urosternito mais longo e estreito e com pilosidade esparsa.

Dimensões (mm). Macho/fêmea. Comprimento total, 15,931,0/23,9-29,4; maior largura do protórax (inclusive os espinhos), 3,8-7,8/5,8-7,2; menor largura do protórax (inclusive os lobos anteriores), 3,2-6,5/4,0-4,7; comprimento do protórax no centro, 2,6-4,8/3,4-4,0; largura umeral, 4,4-8,4/6,8-8,0; comprimento dos élitros, 11,4-20,8/17,2-21,0.

Material-tipo. Holótipo macho (Fig. 11) do BRASIL, Mato Grosso: Sinop (12 ${ }^{\circ} 31^{\prime} \mathrm{S}, 55^{\circ} 37 \mathrm{~W}$ - BR 163, Km 500 a 600 - 350 m), X.1974, Alvarenga \& Roppa col. (MNRJ). Parátipos - PERU, Loreto: Pucallpa, 1 macho, 15.VII.1968, Schunke col. (MNRJ). BRASIL, Rondônia: Vilhena, 1 fềmea, X.1986, O. Roppa, P. Magno \& J. Becker col. (MNRJ). Amazonas: Borba (Lago Acará), 1 macho, XI.1943, A. Parko col. (MZSP). Mato Grosso: 1 fêmea, mesmos dados do holótipo. Santa Catarina: São Bento do Sul (Rio Vermelho), 1 fêmea, XI.1950, Dirings (MZSP).

Discussão. Espécie semelhante a $S$. corticarius e $S$. batesi e difere de ambas por apresentar carenas nos élitros. Difere ainda de $S$. corticarius pelo ápice sutural dos élitros inermes ou apenas salientes, pronoto e élitros com escultura mais forte. 


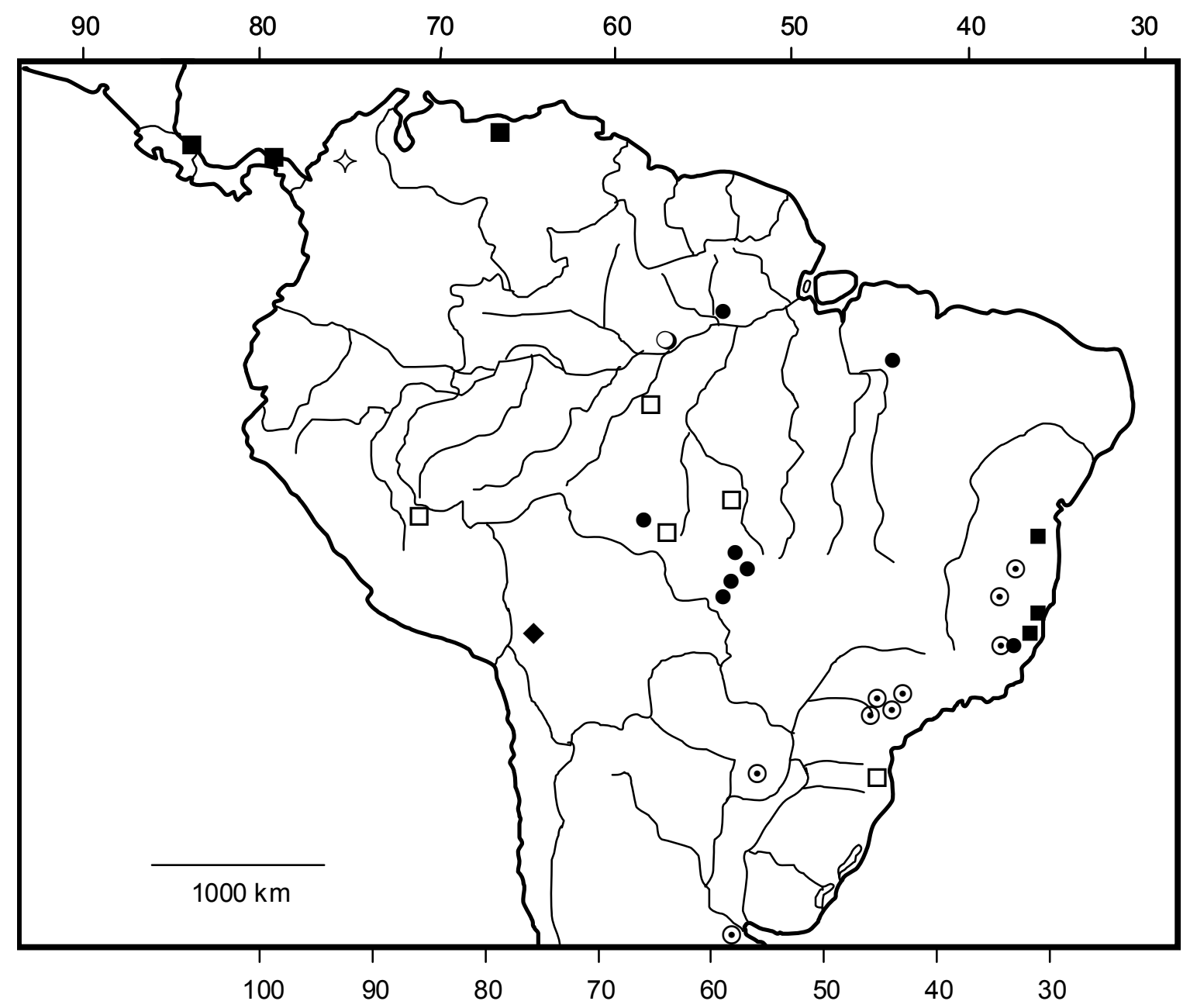

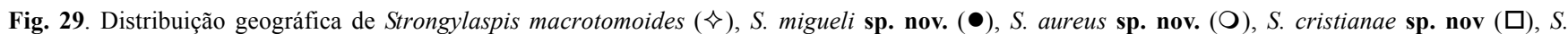
sericeus $(\square)$, S. batesi $(\odot)$, S. bolivianus sp. nov. $(\diamond)$.

Distingue-se de $S$. batesi, pela escultura do escutelo que é constituída por asperezas menores e mais numerosas e ainda pela escultura mais forte do pronoto e dos élitros.

\section{Strongylaspis kraepelini kraepelini Lameere, 1903}

(Figs. 12, 28)

Strongylaspis (Strongylaspis) Kraepelini[sic] Lameere, 1903: 28. Strongylaspis kraepelini kraepelini; Linsley \& Chemsak, 1966: 208; Monné, 1995: 3 (cat.).

Como caracteres distintivos, não mencionados por LAMEERE (1903) e LinsLey \& CHEMSAK (1966), acrescentamos: olhos subaproximados dorsalmente; submento levemente deprimido, com pêlos eretos moderadamente abundantes; borda anterior do submento elevada e estreita; último urosternito das fêmeas, com reentrância centro-apical suave. Estudamos um diapositivo do paralectótipo fêmea, além dos exemplares referidos na lista de material examinado.

Material-tipo. Tippmann (1953) afirmou que os tipos de S. kraepelini foram destruídos juntamente com o Museu de Hamburgo, durante a segunda
Guerra Mundial. LAmeEre (1903) ao descrever a espécie disse que havia quatro machos e três fêmeas do referido museu. Weidner $(1976,1979)$ não relacionou esta espécie na lista dos tipos depositados no ZMUH. Aparentemente, nem todos os exemplares foram devolvidos para a Alemanha. Chemsak \& Linsley (1970) designaram lectótipo (macho) e paralectótipo (fêmea), de Guayaquil, Equador depositados no BMNH e DAmoIseau \& Cools (1987) referiram-se a um síntipo (macho) depositado no ISNB. Portanto, da série sintípica, 2 machos e 2 fêmeas talvez estejam perdidos.

Material examinado. EQUADOR: Manabí: Portoviejo, 1 fêmea, [sem data], Campos col. (MNRJ). San Rafael [Departamento nãodeterminado], 1 fêmea, [sem data], Campos col. (MNRJ).

Strongylaspis kraepelini parvula Linsley \& Chemsak, 1966 (Figs. 13, 28)

Strongylaspis kraepelini parvula Linsley \& Chemsak, 1966: 209; Monné, 1995: 3 (cat.)

Strongylaspis kraepelini; Van Dyke, 1953: 130.

Strongylaspis kraepelini parvula (Fig. 13) difere de $S$. kraepelini kraepelini (Fig. 12), principalmente: pelo aspecto rugoso dos élitros (particularmente do terço anterior) e pelo 
antenômero III cerca de uma vez e meia mais longo que o IV (principalmente nos machos). Em S. kraepelini kraepelini os élitros não tem aspecto rugoso e o antenômero III é subigual ao dobro do IV.

Material-tipo. Holótipo macho, 5 parátipos fêmeas e 17 parátipos machos (CASC); parátipo macho (MZSP); todos de Ilha Santa Cruz, Arquipélago de Galápagos.

Material examinado. EQUADOR, Arquipélago de Galápagos: Isla Santa Cruz, parátipo macho, 2.III.1964, D. Q. Cavagnaro col. (MZSP).

\section{Strongylaspis corticarius (Erichson, 1848)}

(Figs. 14, 18-28)

Ergates corticarius Erichson in Schomburgk, 1848: 571.

Strongylaspis corticarius; Bates, 1884: 234; Monné, 1995: 2 (cat.); Chemsak, 1996: 70; Martínez, 2000: 85.

Strongylaspis (Strongylaspis) corticaria [sic]; Lameere, 1903: 31 (sin.); Buck, 1959: 578.

Strongylaspis scobinatus Thomson, 1860: 313.

Strongylaspis scobinatus var. belti Bates, 1884: 234.

Strongylaspis scobinata [sic]; Gahan, 1895: 82.

Strongylaspis lobulifer Bates, 1892: 145.

Macho. Colorido geral castanho a castanho-avermelhado. Pilosidade geral amarelada. Cabeça, no dorso, com pilosidade curta e pouco aparente e grânulos pequenos e esparsos. Vértice escavado entre os lobos oculares superiores e estes com cerca de 1,5 vezes à largura de um lobo. Carena ocular pouco aparente e restrita ao ápice dos lobos oculares superiores. Suturas coronal e epistomal evidentes e enegrecidas. Clípeo com finas estrias transversais. Labro densamente pontuado e com pilosidade longa, abundante e amarelada. Genas com grânulos pequenos, pilosidade curta e esparsa e ápices arredondados, pouco projetados. Submento com grânulos esparsos e pêlos longos esparsos. Gula brilhante e com pêlos longos e esparsos. Mandíbulas, no dorso, com pêlos longos e esparsos e pontos grossos e confluentes exceto ápice e região ventral, lisos e glabros. Antenas, no máximo, alcançando os ápices elitrais. Escapo não alcançando a margem anterior do protórax, deprimido dorso- ventralmente nos $3 / 4$ basais, com granulação grossa e densa; antenômero III 1,5 vezes o comprimento do escapo e com pontos grossos e densos; IV cerca da metade do comprimento do III; IV-VII com pontos finos e esparsos; VIII$\mathrm{XI}$ inteiramente estriados; XI 1/3 mais longo que o X.

Lados do protórax com crenulado forte ou quase nulo; ângulos anteriores pouco projetados e posteriores com espinho longo em direção à região posterior. Pronoto subglabro ou com grânulos densos ou ainda com duas regiões medianas e ao longo da margem posterior, brilhantes e com pontos finos e grossos e demais área com grânulos pequenos e esparsos. Esternos torácicos com grânulos pequenos e esparsos. Prosterno com pubescência esparsa. Mesosterno, mesepimeros, mesepisternos, metasterno e metepisterno com pêlos longos e abundantes. Escutelo convexo.

Élitros cerca de quatro vezes o comprimento do protórax; finamente pubescentes e com grânulos finos e numerosos no terço basal, gradualmente reduzidos em concentração para o ápice; paralelos nos $2 / 3$ basais e estreitados no terço apical; úmeros com ou sem curta projeção aguçada; ângulo sutural com espinho curto e delgado.

Asas (Fig. 18) com comprimento aproximadamente igual à três vezes a sua maior largura; Costa (C) restrita ao 1/3 basal; Subcosta (Sc) e Radial (R) justapostas logo após a região basal; célula da Radial fechada, de aspecto triangular; s-m retilínea; Setor-Posterior (SP) diferenciada; Média (M) desenvolvida; Média-Anterior (MA) presente; Plical (P) desenvolvida e próximo à base curvada em direção à veia Cubital $(\mathrm{Cu})$; Empusal (E) ligada à base da primeira Anal (1A), separam-se para formar uma célula fechada com um ramo da Empusal b (Eb) e a 1A; ramo a da Empusal (Ea) interrompida na base; Segunda Anal (2A) divide-se logo após a metade de seu comprimento; transversa $2 \mathrm{Aa}$ presente; Jugal (Ju) longa, quase atinge a borda.

Pernas anteriores mais desenvolvidas que as posteriores. Profêmures e protíbias fortemente ásperas. Meso- e metafêmures fortemente pontuados e com grânulos grossos na região ventral. Meso- e metatíbias fortemente pontuadas. Metatarsômero I tão longo quanto os dois seguintes reunidos.

Abdome (Fig. 19) com pilosidade longa e moderadamente densa e pontos finos e densos. Último urosternito transverso e com margem apical sinuosa. Terminália: oitavo tergito (Fig. 20) quadrangular, margem apical arredondada e com cerdas esparsas. Oitavo esternito (Fig. 21) reduzido, bilobado e com pêlos longos e esparsos na margem apical; apófise esternal longa, com cerca do dobro do comprimento do esternito. Arco ventral (Fig. 20) em forquilha, apófise com cerca de 2,5 vezes o comprimento dos braços. Arco dorsal (Fig. 20) desenvolvido, em forma de haste delgada, recurva e com região central pouco dilatada. Tégmen (Figs. 22, 23) com comprimento subigual ao do lobo médio; região distal dividida em parâmeros com cerca de 1/7 do comprimento do tégmen, dotados de cerdas esparsas e com ápices arredondados; peça basal com membrana desenvolvida e região mediana longitudinal pigmentada. Lobo médio (Fig. 24), em vista lateral, levemente curvado; lobo ventral fortemente acuminado no ápice e o dorsal com ápice sinuoso; apófises basais 2,5 vezes mais longas que a porção apical. Saco interno com duas peças paralelas esclerotinizadas e estreitas.

Fêmea. Antenas alcançando o meio dos élitros; escapo mais delgado que nos machos e com pontos finos e densos; antenômero III com pontos finos e esparsos; XI tão longo quanto o X. Pernas anteriores um terço mais curtas que as posteriores. Abdome com pontos finos e densos e pêlos esparsos e amarelados. Urosternitos (Fig. 25) subiguais em largura; urosternito $\mathrm{V}$ estreitado para o ápice e este sinuoso. Urotergito VII (Fig. 25) com forte reentrância na margem apical. Terminália: urosternito VIII (Fig. 26) cerca de 1,5 vezes mais longo que largo; apófise esternal cerca do dobro do comprimento do esternito. Ovipositor tubular, telescopado, invertido (Fig. 26) com o dobro do comprimento do urosternito VIII; evertido (Fig. 27), inclusive membrana intersegmentar, com cerca de 4 vezes do comprimento do urosternito VIII; região distal com um par de lobos curtos; estilos cilíndricos laterais, com cerdas apicais; vulva membranosa e plicada 
longitudinalmente; um par de baculi pouco esclerotinizados; espermateca esclerotinizada, cilíndrica e encurvada; glândula espermatecal mais longa que a espermateca.

Dimensões (mm). Macho/fêmea. Comprimento total, 38,135,7/27,4; maior largura do protórax (inclusive os espinhos), 11,6-10,6/8,2; menor largura do protórax (inclusive os lobos anteriores), 7,8-7,0/5,5; comprimento do protórax no centro, $6,4-$ $6,1 / 4,2$; largura umeral, 11,1-10,8/8,2; comprimento dos élitros, $28,0-26,5 / 20,7$.

Variabilidade. A espécie possui ampla distribuição geográfica (Fig. 28) e apresenta variações notáveis entre os indivíduos: élitros finamente pubescentes ou glabros; o crenulado das laterais do protórax forte ou quase nulo; desenho brilhante da superfície do pronoto inconspícuo ou perceptível; úmeros com ou sem saliência.

Discussão. Foram examinados fotos de síntipos (macho e fêmea) de S. corticarius e diapositivos dos tipos de S. lobulifer, $S$. scobinatus e $S$. scobinatus var. belti. Acreditamos que LAMEERE (1903) estava correto ao colocar as três últimas na sinonímia de $S$. corticarius. Vide outros comentários em $S$. cristianae sp. nov., S. macrotomoides Tippmann, 1953 e S. batesi Lameere, 1903.

Strongylaspis costifer Thomson, 1877 arrolada por MonNÉ (1995) na sinonímia de $S$. corticarius, foi revalidada e transferida para o gênero Protorma Waterhouse, 1880 por TAVAKILIAN (1997).

Material-tipo. De Ergates corticarius: 3 síntipos (2 machos e 1 fêmea) da Guiana (ZMHB); de $S$. scobinatus: holótipo fêmea do México (MNHN); de S. scobinatus var. belti: descrita com base em um número não especificado de exemplares de Chontales, Nicarágua (BMNH); de $S$. lobulifer: holótipo macho de Atoyac, Vera Cruz, México (BMNH).

Material examinado. MÉXICO, Chiapas: Palenque, 1 macho, 79.V.1969, E. Bright \& Campbell col. (MZSP); Tuxtla Gutierrez, 1 fêmea, 2.VII.1965, M. L. Paulson col. (MNRJ). Quintana Roo: X-can, 1 fêmea, 8.VIII.1972, [sem coletor] (MZSP). COSTA RICA, San José: San José, 1 macho, 1 fêmea, 1931, A. Alfaro col. (MZSP). PANAMA, Colón: Ilha Barro Colorado (Zona do Canal), 1 macho, J. Olazarri col. (MNRJ). BRASIL, Roraima: Ilha de Maracá (Rio Uraricoera), 1 macho, 1 fêmea, J. A. Rafael, J. E. B. Brasil, L. S. Aquino col. (MCNZ).

\section{Strongylaspis macrotomoides Tippmann, 1953}

(Figs. 16, 29)

Strongylaspis macrotomoides Tippmann, 1953: 186, pl. 13, fig. 4; Monné, 1995: 3 (cat.); Martínez, 2000: 85.

Strongylaspis macrotomoides assemelha-se a $S$. corticarius, conforme afirmou TIPPMANN (1953), diferindo: desenho brilhante do tegumento do pronoto (Fig. 16) nítido, em forma de "X", com pontuação pouco concentrada; escutelo com asperezas maiores e em menor quantidade; asperezas elitrais mais fortes e presentes até o ápice elitral; espinhos dos ápices elitrais maiores e mais largos na base. Em S. corticarius, alguns exemplares apresentam o desenho pronotal mais ou menos distinto, mas sempre é mais cerradamente pontuado; o escutelo apresenta grânulos finos e numerosos; as asperezas elitrais desaparecem gradualmente em direção ao ápice e os espinhos dos ápices elitrais são menores e delgados.

Material-tipo. Holótipo macho de "Hacienda Pehlke", Colômbia (USNM), estudado através de diapositivo feito por J. S. Moure.

\section{Strongylaspis batesi Lameere, 1903}

(Figs. 15, 29)

Strongylaspis (Strongylaspis) batesi Lameere, 1903: 34; Zajciw, 1970: 2 (nota).

Strongylaspis batesi; Gounelle, 1913: 195 (dist.); Monné, 1995: 2 (cat.).

A descrição original e a redescrição de MELZER (1919), são suficientes para identificar com segurança esta espécie, que é semelhante a $S$. corticarius e difere principalmente: cabeça mais fortemente pontuada; escultura do escutelo, constituída de asperezas bem maiores e em menor quantidade; forma do escutelo, que é mais plano; ângulos suturais dos élitros sem espinhos (apenas salientes); urosternitos menos pilosos.

Variabilidade. A pontuação da cabeça pode ser mais fraca do que na forma típica; a pontuação do pronoto das fêmeas pode ser grossa e concentrada ou fina e esparsa; o escutelo pode apresentar um sulco médio; os élitros são notavelmente alargados no terço médio de alguns exemplares; a pontuação elitral pode ser bem visível; o comprimento do metatarsômero I pode ser subigual aos II-III reunidos; a largura do metatarsômero II pode ser mais acentuada; os élitros podem apresentar espinho fraco no ângulo sutural.

Material-tipo. Lameere (1903) descreveu esta espécie com base em uma fêmea de Buenos Aires, Argentina e uma fêmea e três machos do Espírito Santo, Brasil. Damoiseau \& Cools (1987) afirmaram que há cinco síntipos depositados no ISNB. WeNDT (1984) relacionou um síntipo fêmea como estando depositado no ZMHB. J. S. Moure fotografou um síntipo macho no BMNH. Viklund (comunicação pessoal) informou a existência de dois síntipos no NHRS. É possível que Damoiseau \& Cools (1987) tenham se equivocado ao relacionar cinco síntipos depositados no ISNB, onde só é possível a presença de um síntipo.

Material examinado. BRASIL, Bahia: Encruzilhada (Rodovia RioBahia, km 965 - Motel da Divisa - 960 m), 1 fêmea, XII.1974, Seabra \& Roppa col. (MNRJ). Minas Gerais: Águas Vermelhas, 2 fêmeas, XI.1970, F. M. Oliveira col. (MNRJ). Espirito Santo: Colatina, macho, XI.1972, A. Silva col. (MNRJ). São Paulo: Botucatu, 1 fêmea, X.1963, W. Zikán col. (MZSP); Campinas, 1 macho, 1915, Bondar col. (MZSP); Mogi-mirim (Engenheiro Coelho), 1 fêmea, A. Richtz col. (MZSP); Piracicaba, 1 fêmea, 1914, Bondar col. (MZSP); 1 fêmea, [sem data], Bondar col. (MZSP). PARAGUAI (Parque Nacional Ybycuy), 1 fêmea, 20-25.XI.1989, [sem coletor] (MCNZ). Além desse material, foi examinado o diapositivo de um dos síntipos.

Agradecimentos. Ao Dr. Miguel A. Monné (MNRJ) pelo empréstimo de espécimes e auxilio com material bibliográfico; ao Dr. Ubirajara $\mathrm{R}$. Martins (MZSP) pelo constante apoio e incentivo; ao Dr. Frank Hovore pelas informações e fotos de exemplares-tipos; à Dra. Dilma Solange Napp (DZUP) pelo empréstimo dos diapositivos dos tipos; à Dra. Maria Helena Galileo (MCNZ) pelo empréstimo de material; à Christiana Klingenberg (MZSP) pela tradução do trabalho de Tippmann (1953); ao Dalton T. R. dos Santos pela arte final das ilustrações; ao Sr. Tomasz Huflejt, curador da coleção do ZMPA, pelas informações sobre S. dohrni; ao Dr. Bert Viklund pelas informações sobre S. batesi. 


\section{REFERÊNCIAS}

Bates, H. W. 1872. On the longicorn Coleoptera of Chontales, Nicaragua. The Transactions of the Entomological Society of London 1872: $163-238$.

Bates, H. W. 1884. Biologia Centrali-Americana, suppl. to Longicornia. London, 5: 225-248.

Bates, H. W. 1892. Additions to the Longicornia of Mexico and Central America, with remarks on some of the previously recorded species. The Transactions of the Entomological Society of London 1892: $143-183$.

Buck, P. 1959. Cerambycidae in der Sammlung des Instituto Anchietano de Pesquisas. Pesquisas 3: 577-609.

Chemsak, J. A. 1996. Illustrated Revision of the Cerambycidae of North America. I. Parandrinae, Spondylidinae, Aseminae, Prioninae. Burbank, Wolfsgarden Books, $x+149$ p, 10 est.

Chemsak, J. A. \& E. G. Linsley. 1970. Additional designations of lectotypes of neotropical Cerambycidae in the collections of the British Museum (Natural History). Journal of the Kansas Entomological Society 43(4): 404-417.

Chemsak, J. A.; E. G. Linsley \& F. A. Noguera. 1992. Listados faunísticos de México. II. Los Cerambyicidae y Disteniidae de Norteamérica, Centroamérica y las Indias Occidentales (Coleoptera). México, D. F. Universidad Nacional Autônoma de México, 204 p.

Damoiseau, R. \& J. Cools. 1987. Liste du materiel typique conservé dans les collections entomologiques de l'Institut royal des Sciences naturelles de Belgique. Coleoptera, Cerambycoidea, Cerambycidae: Aseminae, Cerambycinae, Disteniinae, Lepturinae, Parandrinae, Prioninae et Spondylinae. Documents de travail, Bulletin del' Institut Royal des Sciences Naturelles de Belgique 42: 1-39.

Erichson, W. F. 1848. Die Insekten. In: R. Schomburgk, R. Reisen in Britisch-Guiana. Leipzig: J. J. Weber, 3: 533-617.

Fragoso, S. A. \& M. A. MonNÉ. 1995. Notes on Macrotomini (Coleoptera, Cerambycidae, Prioninae). Revista Brasileira de Biologia 55(2): $215-225$

Gahan, C. J. 1895. On the longicorn Coleoptera of the West Indian islands. The Transactions of the Entomological Society of London 1895: 79-140.

GounelLe, E. 1913. Chasses de M. E.-R. Wagner, correspondant du Muséum, dans les provinces du Nord de la République Argentine. Cérambycides nouveaux ou peu connus. Bulletin du Muséum National d'Histoire Naturelle de Paris 19(4): 193-231.

Júlio, C. E. A.; J. A. Giorgi \& M. A. Monné. 2000. Os tipos primários de Cerambycidae (Coleoptera) da coleção do Museu Nacional - Rio de Janeiro. Publicações Avulsas do Museu Nacional, Rio de Janeiro 84: 1-54.

Lacordaire, J. T. 1869. Histoire Naturelle des Insectes. Genera dos Coléoptères, ou exposé méthodique et critique de tous les genres proposés jusqu'ici dans cet ordre d'insectes. Paris, Librairie Encyclopédique de Roret, 8: 1-552.

Lameere, A. 1903. Révision des prionides (Septième mémoire). Mémoires de la Société Entomologique de Belgique 11: 1-216.

LAMEerE, A. 1912. Révision des prionides (Vingtième mémoire - Prionines VII). Annales de la Société Entomologique de Belgique 56: $185-260$.

Lameere, A. 1915. Note sur quelques Prioninae (Col., Cerambycidae de la collection Em. Gounelle.) Annales de la Société Entomologique de France 84: 283-286.

Linsley, E. G. \& J. A. Chemsak. 1966. Cerambycidae of the Galápagos Islands (Coleoptera). Occasional Papers of the California Academy of Sciences (4) 33(8): 197-236.

Marinoni, R. C. \& L. M. Almeida. 1983. Sobre a venação alar em Coccinellidae e Cerambycidae (Coleoptera). Revista Brasileira de Entomologia 27(3/4): 267-275.

Marques, M. I. \& D. S. NAPP. 1996. Revisão e transferência para Rhopalophorini (Coleoptera, Cerambycidae, Cerambycinae) dos gêneros Coremia A.-Serville, 1834 e Merocoremia Marques, 1994. Revista Brasileira de Entomologia 40(3/4): 379-423.

MARTínez, C. 2000. Escarabajos Longicornios (Coleoptera: Cerambycidae) de Colombia. Biota Colombiana 1(1): 76-105.

Melzer, J. 1919. Os longicórnios brazileiros da subfamilia "Prioninae", tomando em consideração particular as espécies do Estado de São Paulo. Revista do Museu Paulista 11: 1-207.

Monné, M. A. 1995. Catalogue of the Cerambycidae (Coleoptera) of the Western Hemisphere. Part XXII. São Paulo, Sociedade Brasileira de Entomologia, 115p.

NAPP, D. S. 1994. Phylogenetic relationships among the subfamilies of Cerambycidae (Coleoptera, Chrysomeloidea). Revista Brasileira de Entomologia 38(2): 265-419.

Noguera, F. A. \& J. A. Chemsak. 1996. Cerambycidae (Coleoptera), p. 381-409. In: Biodiversidad, taxonomia y biogeografía de artrópodos de México: Hacia una síntesis de su conocimiento. México D. F., Instituto de Biologia, Ciudad Universitaria.

TAVAKILIAN, G. L. 1997. Nomenclatural changes, reinstatements, new combinations, and new synonymies among American Cerambycids (Coleoptera). Insecta Mundi 11(2): 129-139.

Thomson, J. 1860. Essai d'une classification de la famille des cérambycides et matériaux pour servir a une monographie de cette famille. Paris, 404 p.

Tippmann, F. F. 1953. Studien über neotropische Longicornier I (Coleoptera; Cerambycidae). Dusenia 4: 181-228.

Van Dyke, E. C. 1953. The Coleoptera of the Galápagos Islands. Occasional Papers of the California Academy of Sciences 22: 1181

Weidner, H. 1976. Die Entomologischen Sammlungen des Zoologischen Instituts und Zoologischen Museums der Universität Hamburg, IX Teil, Insecta VI, (Coleoptera). Mitteilungen aus dem Hamburgischen Zoologischen Museum und Institut 73: 87264.

WeidNER, H. 1979. Die Entomologischen Sammlungen des Zoologischen Instituts und Zoologischen Musuems der Universität Hamburg, Nachtrag zum IX. Teil, Insecta VI, (Coleoptera). Mitteilungen aus dem Hamburgischen Zoologischen Museum und Institut 76: $395-468$

Wendt, H. 1984. Die Cerambyciden-Typen (Coleoptera, Phytophaga) des Zoologisches Museums Berlin. Teil I: Unterfamilie Prioninae. Mitteilungen aus dem Zoologischen Museum in Berlin 2: 327-342.

ZAJciw, D. 1970. Notas sôbre o gênero Strongylaspis Thoms., 1860, com descrição de uma espécie nova do Brasil (Coleoptera, Cerambycidae, Prioninae). Atas da Sociedade de Biologia do Rio de Janeiro 14(1-2): $1-3$. 